\title{
EDITORIALS \\ How Editors of psychiatric journals perceive their role? A follow-up appraisal seven years after
}

\author{
EDITORIALI \\ Come gli Editor delle riviste di psichiatria percepiscono il loro ruolo? \\ Una rivalutazione di follow-up, sette anni dopo
}

\author{
MICHELE TANSELLA, Editor
}

In 2003 EPS published six Editorials, written by the Editors of six psychiatric Journal that were invited to describe their job and the main problems they were facing in dealing with various aspects of their task. In my letter of invitation to the other Editors I did not ask any specific question. My goal was simply to collect the views of the Editors of five widely read and well established international journals and of the Editor of a new one, recently launched (the official Journal of the World Psychiatric Association, just appeared in February 2002). They were the Editors of Acta Psychiatrica Scandinavica (Povl Munk Jorgensen), The British Journal of Psychiatry (Greg Wilkinson), Psychological Medicine (Eugene Paykel), Psychotherapy and Psychosomatics (Giovanni A. Fava), Social Psychiatry and Psychiatric Epidemiology (Paul Bebbington) and World Psychiatry (Mario Maj). All six Editors were based in Europe and were possibly representatives of the European view on the matter. The title of my presentation of these Editorials was "Editing a psychiatric journal in a changing world". As expected I was not able to make comparisons between the different views expressed by these Editors and to summarize their views in a single overall summary. Most of them were descriptive, and were dedicated to various issues: how to make and circulate a Journal; how to achieve excellence, how to improve their Impact Factor, and the problem of choosing between an open or a blind review process. Some also dealt with the likely change in the near future to online versions, the general issue of conflicts of interest, and the credibility of medical journals. They also mentioned the difficulties in mediating the relationships between authors and referees, and the need to increase the access of the average psychiatrist to international psychiatric journals.

I thought it was interesting to repeat the same exercise after seven years and in the summer of 2009 I invited again the Editors of four of those Journals, namely Acta Psychiatrica Scandinavica, The British Journal of Psychiatry, Psychological Medicine and World Psychiatry
Nel 2003 EPS ha pubblicato sei Editoriali, scritti dagli Editor di sei riviste di psichiatria, che erano stati invitati a descrivere il loro lavoro e i principali problemi da loro incontrati nel far fronte a vari aspetti del loro compito. Nella mia lettera di invito non avevo fatto domande specifiche. Il mio scopo era semplicemente quello di raccogliere i punti di vista di cinque Editor di riviste internazionali molto diffuse e di grande tradizione, e quello di un Editor di una nuova rivista internazionale, organo ufficiale della World Psychiatric Association, che era uscita a Febbraio dell'anno precedente. Coloro che erano stati invitati erano gli Editor di Acta Psychiatrica Scandinavica (Povl Munk Jorgenesen), di Psychological Medicine (Eugene Paykel), di Psychotherapy and Psychosomatics (Giovanni A. Fava), di Social Psychiatry and Psychiatric Epidemiology (Paul Bebbington) e di World Psychiatry (Mario Maj). Questi sei Editor, che operavano tutti in Europa, potevano verosimilmente essere considerati rappresentativi di una visione europea sul tema in questione. Il titolo della mia presentazione degli Editoriale era Dirigere una rivista di psichiatria in un mondo in cambiamento. Come previsto, in quella presentazione non fu possibile fare confronti tra le diverse opinioni espresse e riassumere in un unico quadro le analisi fatte indipendentemente dai vari Editor. La maggior parte di quelle analisi erano ovviamente descrittive, dedicate ad aspetti diversi: come fare e come far circolare una rivista, come perseguire l'eccellenza e migliorare l'Impact Factor, se scegliere tra una revisione degli articoli in aperto o in cieco, il probabile passaggio, nel futuro prossimo, a versioni on line delle riviste, il problema del conflitto di interesse e della credibilità delle riviste di medicina, le difficoltà nel mediare le relazioni tra gli autori e i referee, la necessità di aumentare l'accesso dello "psichiatra medio" alle riviste internazionali, ed altro ancora.

Nell'estate del 2099 ho pensato che sarebbe stato interessante ripetere lo stesso esercizio a distanza di sette anni e ho invitato di nuovo gli Editor di quattro delle sette riviste (Acta Psychiatrica Scandinavica, il British Journal of Psychiatry,

Epidemiologia e Psichiatria Sociale, 19, 3, 2010 
to describe again their perception of the Editor's job. This time, in my letter of invitation, I specified that I would have liked to have their views on the following five topics:

- To what extent the situation has changed, in these seven years? From your privileged position can you described any changes that have occurred in scientific approach, in the topics more frequently investigated, in the quality of papers submitted, and in the policies adopted in various countries for promoting research in mental health?

- To what extent the predictions made seven years ago by you and other Editors have been confirmed?

- From your perspective what are the main differences between European and North American psychiatric Journals? Do they reflect different approaches in conducting psychiatric research between the two sides of the Atlantic?

- Try to look ahead: How will your Journal look like in five years time?

- Jens Frederik Refeldt, an outstanding Danish scientist, wrote in 2001 that "science is not science until it has been published". One of the scopes of scientific biomedical research is to improve the treatment and the outcome of diseases. We could perhaps say, stimulated by the Refeldt's statement, that a scientific discovery is confirmed as a discovery when is shown to improve everyday clinical practice. In relation to mental disorders how can we improve the implementation in mental health care of new discoveries, and there is a role for scientific psychiatric journals for facilitating and stimulating this improvement?

Perhaps not surprisingly, the Editors' reactions to this more structured, second invitation have not changed very much, compared with those following the first unstructured request. The five questions schema has not been followed and each Editor preferred to develop his own schema in structuring his reflections.

Povl Munk Jorgensen (2010) dedicated his Editorial to discuss "the increasingly infiltrating mutual mistrust and paranoia in publishing - thinking of authors as potential cheaters and criminals, or persons behaving unethically to gain money and prestige". It asked himself if it is true that part of the time and energy of an Editor is presently spent in handling the risk of cheat, fraud, unethical behavior, biases and other irregularities among authors and reviewers. Moreover, in considering if this is becoming more important than the science and the research published. The reply was given some years ago to the present Editor of Acta by the now retired managing director of the company publishing that Journal: "Your responsibility is to give the contents of the Acta Psychiatrica Scandinavica the highest possible quality. The rest ... will be taken care of in the publishing
Psychological Medicine e World Psychiatry) a descrivere nuovamente la percezione che essi hanno del loro lavoro. Questa volta, nella mia lettera di invito, ho specificato cinque punti sui quali avrei voluto avere la loro opinione:

- In che misura la situazione era cambiata, in questi sette anni? Quali erano stati, visti dal loro osservatorio privilegiato, i principali cambiamenti negli approcci scientifici, nei temi più frequentemente fatti oggetto di ricerca, nella qualità dei lavori inviati per la pubblicazione, nelle politiche adottate nei vari Paesi per promuovere la ricerca sulla salute mentale?

- In che misura le previsioni fatte sette anni prima erano state confermate?

- Quali erano le differenze, viste dalla loro prospettiva, tra riviste europee e riviste americane? Riflettevano queste differenze approcci diversi nella ricerca scientifica, nei due versanti dell'Atlantico?

- Provate a guardare avanti. Come sarà la vostra rivista tra cinque anni?

- Jens Frederik Refeldt, un famoso scienziato danese, nel 2001 ha scritto: la scienza non è scienza fino a che non è pubblicata. Uno degli scopi della ricerca scientifica biomedica è migliorare il trattamento e l'esito delle malattie. Potremmo allora dire, parafrasando Refeldt, che una scoperta scientifica si conferma come scoperta quando si può provare che essa ha migliorato la pratica clinica quotidiana. Per quanto riguarda i disturbi mentali come possiamo migliorare l'implementazione nella pratica clinica delle nuove scoperte e le riviste scientifiche possono avere un ruolo nel migliorare questa implementazione?

Le reazioni degli Editor a questo secondo, più strutturato invito non sono cambiate di molto rispetto alla prima volta, nella quale non era stata posta alcuna domanda specifica. Lo schema suggerito dalle suddette cinque domande non è stato, infatti, seguito e ciascun Editor ha preferito strutturare le sue riflessioni secondo un suo schema.

Povl Munk Jorgensen (2010) ha dedicato il suo Editoriale alla discussione della crescente, reciproca paranoica sospettosità tra Editor ed autori, che fa pensare ai primi che i secondi siano potenziali imbroglioni e criminali, o persone che si comportano in modo non etico per guadagnare denaro e prestigio. Egli si è chiesto allora in quale misura sia vero che una parte importante del tempo e dell'energia di un Editor siano attualmente spesi per fronteggiare il rischio di imbrogli, di frodi, di comportamenti non etici e di altre irregolarità, da parte di autori e di referee e se ciò non sia per caso diventato più importante della scienza e della ricerca. La risposta è stata data all'attuale Editor di Acta, qualche anno fa, dal direttore della casa editrice, ora in pensione: la sua responsabilità, in quanto Editor, è assicurare il massimo di qualità a ciò

Epidemiologia e Psichiatria Sociale, 19, 3, 2010 
company". I wonder to what extent this applies to the majority of leading psychiatric journals around the world.

Peter Tyrer (2010) in his Editorial discusses in detail each of the targets he set himself when he became Editor of the British Journal of Psychiatry in 2003, namely: the journal should be both topical and learned, to have both immediate and long-term impact, to appeal equally to the busy clinician and the earnest researcher, and to be both serious and entertaining. He also remembered to give a reply to my fourth question and predicted that the "yellow journal", in five years time, will be read on I-phones long before it will drop through the letter box. I appreciate his critical view on Impact Factor (the focus on impact factor can be unfair yet despite these criticism we, as yet, have no other comparable index which is better than the impact factor ... and it is likely to remain for a little longer yet). I also liked his citation of Thomas Wakley's (the founder of the Lancet in 1823) three cardinal aims: to entertain, instruct and reform. In other words, we could say that if a psychiatric journal, as the contemporary biomedical research, should be both "theory enhancing" and "change promoting" (see for further details in Tansella, in press), this should be achieved with a touch of entertainment, which is, according to Tyrer (2010) the "best form of education".

Carmine Pariante, Associate Editor of Psychological Medicine, reporting on his relatively recent experience, states that among the many problems that an Editor encounters, it is worth remembering the need to anticipate trends, investigate misbehaviours, settle ethical disputes and interface with the lay press (Pariante, 2010). So an Editor should be a guarantor of the quality (compared to few years ago papers published today in the same journal are better, so publishing in high-impact journals is becoming more and more difficult); a gatekeeper (in Psychological Medicine up to $50 \%$ of papers do not go to referees and are rejected by the editors); a journalist (the papers need to be clinically relevant and to reach an audience larger than just scientists and should ideally be picked up by the press); a movie producer (a good paper needs to have a clear story-line, should move the reader and should deal with problems that are socially or clinically important, or difficult to resolve); a fashion guru (the Editor should create the new trends, should be innovative, visionary and brave, while on the other side referees tend to be conservative); a detective (discover when a paper is not novel); $a$ moral arbiter (the Editor deals with letters of complaint, appeals and re-appeals, attacks; and finally must be able to understand the commercial basis of scientific publishing).

Finally Mario Maj informed us about the recent developments of World Psychiatry (Maj, 2010), published now in five languages and reaching more than 33,000 psychiatrists in 121 countries. Not surprisingly its first Impact Factor was pretty high (3.896, in 2008). The Journal has the che viene pubblicato. A tutto il resto ... pensa la Casa Editrice. Mi chiedo in che misura ciò sia vero per la maggior parte delle riviste scientifiche, in giro per il mondo.

Peter Tyrer (2010), nel suo Editoriale discute in dettaglio ciascuno degli obiettivi che si pose quando nel 2003 assunse la direzione del British Journal of Psychiatry, vale a dire: la rivista deve essere al tempo stesso aggiornata e culturalmente valida, deve avere un impatto immediato ed a lunga distanza, deve interessare il clinico ed il ricercatore, deve essere seria e divertente. Egli si è poi ricordato di rispondere al mio quarto quesito, facendo la previsione che, tra cinque anni, la rivista sarà probabilmente letta sugli smarth phone prima che il postino possa consegnare la versione cartacea. Ho apprezzato la sua visione critica dell'Impact Factor (il focus sull'Impact Factor può essere non equo - ma, nonostante tutte le critiche che è possibile fare ad esso, non esiste ancora un altro indicatore migliore ... ed esso è quindi destinato a sopravvivere per un po'). Mi è piaciuta anche la sua citazione di Thomas Wakley, il fondatore nel 1823 della rivista The Lancet, che menzionò tre scopi cardinali: intrattenere, istruire e riformare. Possiamo allora dire che, se una rivista scientifica, come la ricerca biomedica contemporanea, deve essere al tempo stesso theory enhancing (deve sviluppare le teorie di base) e change promoting (deve essere capace di promuovere innovazione e cambiamento) (Tansella, in press), ciò deve essere fatto con la "mano leggera", con un tocco di divertimento, con entertainment, che secondo Tyrer (2010) è la miglior forma di didattica.

Carmine Pariante, Associate Editor di Psychological Medicine, facendo riferimento alla sua relativamente recente esperienza, dice che, tra i molti problemi che un Editor deve affrontare, bisogna includere la necessità di anticipare i trend, di indagare sui comportamenti scorretti, di risolvere le dispute etiche e di avere buone relazioni con la stampa (Pariante, 2010). Quindi un Editor deve essere il garante della qualità (se si confrontano con quelli pubblicati pochi anni fa sulle stesse riviste, i lavori di oggi sono migliori, quindi sarà sempre più difficile pubblicare su buone riviste), un sorvegliante con funzioni $d i$ filtro (fino al $50 \%$ dei lavori inviati a Psychological Medicine non vanno ai referee e sono respinti in prima battuta dagli Editor), un giornalista (gli articoli devono essere clinicamente rilevanti e devono raggiungere un pubblico più vasto degli addetti ai lavori, devono idealmente raggiungere i media), un produttore cinematografico (un buon articolo deve avere una "storia" chiara, deve interessare il lettore e deve riguardare problemi socialmente e clinicamente rilevanti, o difficili da risolvere), uno stilista (deve saper creare nuovi trend, deve essere innovativo, deve guardare al futuro con immaginazione e coraggio), un detective (deve scoprire gli articoli non realmente nuovi) e, infine, deve essere un arbitro morale

Epidemiologia e Psichiatria Sociale, 19, 3, 2010 
objective to inform as many psychiatrists as possible in a language simple to understand and to give voice to psychiatrists of all regions of the world, disseminating psychiatric research conducted in low and middle income countries.

None of the four Editors accepted my suggestion to compare European and American psychiatric journals, but Tyrer, who briefly discussed some of the features of two leading American journals, Archives of General Psychiatry and American Journal of Psychiatry.

Editing a psychiatric journal is a difficult and responsible job. The Editors should remember that their ultimate goal is to improve practice for providing better care for our patients. Simple diffusion and passive dissemination of information, made by scientific journals while they stimulate new ideas, are at the same time necessary and useful, but not sufficient at changing practice. One example of the actions by politicians to change practice, not based on solid research, has been recently critically illustrated by Cooper (2009), in relation to the new programme called Improving Access to Psychological Therapies (IAPT). This programme aims to expand treatment services by training 3,600 'psychological therapists' in cognitive behavioural therapy (CBT), which they will then apply in the wider community. It has an initial budget of $£ 173$ million. However, closer examination raises questions concerning the project's theoretical basis, logistics and research methodology, and casts doubt on its advantages over alternative approaches. The results of a study showing these advantages has never been published, simply because it has have never been conducted.

What is actually done in clinical care, after new information is provided by scientific journals, is out of the control of the Editors. In conclusion, for editing a journal we need not only experience and ethical commitment, but also rules, standards and good models. But which is the best model? According to Box (1979), a statistician, All models are wrong, but some are useful. This dictum applies in many fields.

\section{REFERENCES}

Box G.E.P. (1979). Robustness in Statistics. Academic Press: London. Cooper B. (2009). Strange bedfellows: economics, happiness and mental disorder. Epidemiologia e Psichiatria Sociale, 18, 208-213.

Maj M. (2010). World Psychiatry and the WPA task force to promote dissemination of psychiatric research conducted in low and middle income countries. Epidemiologia e Psichiatria Sociale, 19, 204-206.

Munk Jorgensen P. (2010). Authors are not criminals and editors should not be policemen. Epidemiologia e Psichiatria Sociale, 19, 193-195.

Pariante C.M. (2010). The many lives of an (associate) editor. Epidemiologia e Psichiatria Sociale, 19, 200-203.

Tansella M. (in press). La psichiatria tra ricerca "theory enhancing", ricerca "change promoting" e pratica clinica. Una sfida sostenibile. In Essential Psychiatry. (ed. R.M. Murray, K.S. Kendler, P. McGuffin, S. Wessely, D.J. Castle) (Cambridge University Press: Cambridge) (deve avere a che fare con lamentele, ricorsi, attacchi, deve essere esperto di questioni relative alla pubblicazione delle riviste scientifiche).

Infine, Mario Maj ci ha informati sui recenti sviluppi di World Psychiatry (Maj, 2010), che è ora pubblicato in cinque lingue ed inviata più di 33.000 psichiatri, in 121 Paesi. Non ci si sorprende quindi che il suo primo Impact Factor sia stato piuttosto alto (3.896, nel 2008). Questa rivista ha l'obiettivo di informare il maggior numero possibile di psichiatri, usando un linguaggio comprensibile a tutti, di dare voce agli psichiatri di tutte le regioni del mondo, di disseminare i risultati della ricerca condotta in Paesi con basso o medio reddito medio.

Nessuno degli Editor ha accettato il mio suggerimento di confrontare le riviste psichiatriche europee ed americane, tranne Tyrer, che ha discusso brevemente alcune caratteristiche di due riviste americane leader, Archives of General Psychiatry e American Journal of Psychiatry.

Fare l'Editor di una rivista di psichiatria è un lavoro difficile e con molte responsabilità. Dobbiamo ricordare che il nostro obiettivo finale è migliorare la pratica clinica, per fornire una migliore assistenza ai nostri pazienti.

La semplice diffusione e disseminazione passiva di informazioni, che è uno dei compiti delle riviste scientifiche insieme a quello di stimolare nuove idee, sono al tempo stesso necessarie ed utili, ma insufficienti per cambiare la pratica. Un esempio delle azioni dei politici dedicate al cambiamento, che non sono sempre basate su solide ricerche scientifiche, è stato criticamente riportato da Cooper (2009), in riferimento al nuovo Programma denominato Improving Access to Psychological Therapies (IAPT), Questo programma, che ha lo scopo di formare 3600 terapisti in tecniche di terapia comportamentale per il trattamento dell'ansia e della depressione nella comunità, ha un budget iniziale di 173 milioni di sterline. Tuttavia, ad un'analisi attenta sono emersi molti dubbi sulle basi teoriche del progetto, sulla metodologia e sui suoi vantaggi rispetto ad approcci alternativi. Uno studio che dimostri questi vantaggi non è mai stato pubblicato su di una rivista scientifica, semplicemente perché non è mai stato condotto.

Ciò che si fa nella pratica clinica, dopo le nuove informazioni fornite dalle riviste scientifiche, è fuori del controllo degli Editor. In conclusione, per dirigere una rivista scientifica abbiamo bisogno non solo di esperienza e di impegno etico, ma anche di regole, di standard e di buoni modelli. Ma qual è il modello migliore? Secondo Box (1979), uno statistico, "tutti i modelli sono sbagliati, alcuni però sono utili". Un detto che si può applicare a molti campi di studio.

Edizione Italiana Fondamenti di Psichiatria, CG Edizioni Medico Scientifiche: Torino.

Tyrer P. (2010). The place of the British Journal of Psychiatry in the mental health league. Epidemiologia e Psichiatria Sociale, 19, 196-199. 